\title{
Crude glycerol in the diets of the juveniles of Amazon catfish(female Pseudoplatystoma punctifer $x$ male Leiarius marmoratus)
}

\author{
Vanessa Bezerra da Silva Rôxo*, Sandro Estevan Moron, Deborah Alves \\ Ferreira, Maria Paula Balduino Jorge
}

Universidade Federal do Tocantins,Araguaína, Tocantins, Brasil.

*E-mail:vanessabio@outlook.com

\begin{abstract}
This research aimed to determine the best inclusion level of crude glycerol in the diet of the Amazon catfish (Pintado), through zootechnical performance, body composition, metabolic profile and histopathology. The experiment was conducted at the Laboratory of Morphophysiology and Biochemistry of Neotropical Fishes of the Federal University of Tocantins. There was used 150 juvenilles of pintado, these with initial weight of $6,83 \pm 1,11(\mathrm{~g})$ and 10,06 $\pm 0,57(\mathrm{~cm})$ lenght in a completely randomised design, with 3 replications (10 animals in each one). They were fed with five diets containing increasing levels of glycerol $\left(0 \mathrm{~g} \mathrm{~kg}^{-1}, 50 \mathrm{~g} \mathrm{~kg}^{-}\right.$ ${ }^{1}, 75 \mathrm{~g} \mathrm{~kg}^{-1}, 100 \mathrm{~g} \mathrm{~kg}^{-1}$, and $\left.125 \mathrm{~g} \mathrm{~kg}^{-1}\right)$ during 90 days (30 days of adaption and 60 experimental days). The indexes were evaluated and they did not present statistical difference between each other, except for the specific growth rate, which showed a moderate linear behavior and muscular glycogen that at the level of $125 \mathrm{~g} \mathrm{~kg}^{-1}$ presented a lower concentration compared with the control diet $\left(0 \mathrm{~g} \mathrm{~kg}^{-1}\right)$. Regarding histology, the crude glycerin did not cause significant hepatic and renal changes in the referred specie, since the alterations found in the two tissues were considered lesions that did not compromise the functioning of the organ or that are reversible. Finally, it was indicated that the juveniles of Amazon Pintado are able to metabolize the crude glycerin up to $100 \mathrm{~g} \mathrm{~kg}^{-1}$ level.
\end{abstract}

Keywords-biodiesel, fishfarming, hematology, metabolism, performance.

\section{INTRODUCTION}

The accentuatepopulation growthentails some implications such as the increasingdemand for basic inputs inherent to survival. This is why the scientific community has focused its attention on issues that promote the perpetuation of humanity and the sustainability of the planet, such as the development of renewable energy sources and the increase of food production.
Thus, the production of biodiesel has been highlighted as an alternative to fossil fuels, which are considered the main responsible for the greenhouse gases emissions as carbon dioxide, for example. In a national scenario biodiesel started to stand out with greater intensity starting in 2010, after the ratification of the mandatory use of biodiesel together with diesel from fossil fuels, according to current national legislation.

However, biodiesel production generates a significant amount of byproduct known as crude glycerol and it has a high polluting potential when not disposed of correctly. A possible solution to this problem is the use of this glycerol as an alternative food for farm animals, because besides the advantages linked to its bioavailability, glycerol has a low cost.

The fish farming has been one of the research areas that have tested this byproduct as an alternative food. Even though it is a sector that contributes to the world food production, it faces some obstacles that make it difficult to expand, such as a the need for dietary ingredients, which are available in small quantities. As a result the production costs increases, since food represents between 70 and $90 \%$ of the production costs of captive fish.

Studies that have investigated the use of crude glycerin in fish diets are still in the beginning. Hence, in view of the current scenario of growth in aquaculture and biodiesel production, the search for information in association with animal experimentation on the use of this b-product as an energy ingredient in the fish diet is essential to evaluate the substitution of conventionally used dietary energy sources and for the foundation of later studies with glycerol in fish nutrition.

The present work was conducted with the aim of determining the best level of the inclusion of glycerol in the diet of the hybrid Amazon catfish "Pintado" by the evaluation of zootechnical performances, body composition, metabolic profile and histopathology. 


\section{MATERIAL AND METHODS}

\subsection{Experimental Design}

The experiment was conducted in the School of Veterinary Medicine and Animal Sciende of the Federal University of Tocantins - UFT, Araguaína Campus - TO, at the Laboratory of Morphophysiology and Biochemistry of Neotropical Fishes, from january to april 2017. Following the standards written in the Law of Procedures for Scientific use of Animals of the Federal University of Tocantins, the process number is 23101.005896/2016-56. There was used 150 juvenilles of pintado, these with initial weight of $6,44 \pm 0,89(\mathrm{~g})$ and $10,06 \pm 0,57 \mathrm{~cm}$ lenght, they were displaced in fiber boxes with 1000 liters capacity and constant water flow. Five treatments were tested with three repetitions (fiber boxes) and 10 animals per experimental unity. The experimental design used was completely randomised design (DIC). The diets were created to be isoproteic and isoenergetic and all the nutritional requirements were met, according to Almeida (2014). The treatments consisted of five experimentais diets and four of them with inclusion level $\left(50 \mathrm{~g} \mathrm{~kg}^{-1}, 75 \mathrm{~g}\right.$ $\mathrm{kg}^{-1}, 100 \mathrm{~g} \mathrm{~kg}^{-1}$, and $125 \mathrm{~g} \mathrm{~kg}^{-1}$ ) of crude glyrecol in partial substitution of maize and a control treatment as reference (no inclusion of glycerol) (Table1).

Table.1: Percentage and chemical composition of the experimentais diets with different glycerol levels for the pintado juveniles.

\begin{tabular}{|c|c|c|c|c|c|}
\hline \multirow[b]{2}{*}{ INGREDIENTS } & \multicolumn{5}{|c|}{ Inclusion Level } \\
\hline & $0 \mathrm{~g} \mathrm{~kg}^{-1}$ & $50 \mathrm{~g} \mathrm{~kg}^{-1}$ & $75 \mathrm{~g} \mathrm{~kg}^{-1}$ & $100 \mathrm{~g} \mathrm{~kg}^{-1}$ & $125 \mathrm{~g} \mathrm{~kg}^{-1}$ \\
\hline Viscera flour & 55,00 & 55,00 & 55,00 & 55,00 & 55,00 \\
\hline Soy flour & 21,43 & 22,45 & 22,96 & 23,47 & 23,98 \\
\hline Feather meal & 4,00 & 4,00 & 4,00 & 4,00 & 4,00 \\
\hline Farelo de milho & 18,56 & 12,54 & 9,53 & 6,52 & 3,51 \\
\hline Crude glycerol & 0,00 & 5,00 & 7,50 & 10,00 & 12,50 \\
\hline Nucleus $^{1}$ & 1,00 & 1,00 & 1,00 & 1,00 & 1,00 \\
\hline \multirow[t]{2}{*}{ TOTAL } & 100,00 & 100,00 & 100,00 & 100,00 & 100,00 \\
\hline & \multicolumn{5}{|c|}{ Requirements } \\
\hline Calcium (\%) & 2,69 & 2,69 & 2,69 & 2,69 & 2,69 \\
\hline Gross energy $(\mathrm{Kcal} / \mathrm{kg})$ & 4630 & 4626 & 4623 & 4621 & 4619 \\
\hline \multicolumn{6}{|l|}{ Metabolizable energy } \\
\hline$(\mathrm{Kcal} / \mathrm{kg})$ & 1,36 & 1,38 & 1,39 & 1,40 & 1,41 \\
\hline Ethereal extract $(\%)$ & 9,02 & 8,82 & 8,72 & 8,62 & 8,52 \\
\hline Crude protein $(\%)$ & 42,00 & 42,00 & 42,00 & 42,00 & 42,00 \\
\hline Crude fiber $(\%)$ & 2,02 & 1,96 & 1,93 & 1,90 & 1,87 \\
\hline Total phosphorus (\%) & 1,63 & 1,62 & 1,62 & 1,61 & 1,61 \\
\hline Total lysine $(\%)$ & 2,59 & 2,61 & 2,62 & 2,62 & 2,63 \\
\hline Total methionine $(\%)$ & 0,80 & 0,79 & 0,79 & 0,79 & 0,79 \\
\hline
\end{tabular}

${ }^{1}$ Micronutrient levels per kilogram of product: folic acid 20,25mg; antioxidant 66,15mg; cobalt 33,75mg; copper 337,50mg; iron $337,50 \mathrm{mg}$; iodine $50,62 \mathrm{mg}$; manganese $1350,00 \mathrm{mg}$; methionine 1,20mg; calcium pantothenate $315,56 \mathrm{mg}$; selenium 10,12mg; sodium 55,58mg; tyrosine 810,00mg; vit. A 216. 000U.I/kg; vit. B1 45.56mg; vit. B2135,00mg; vit. B6 67,50 mg; vit. D3 50.625,00UI/kg; vit. E 506.25UI/kg; vit. H 2.70mg; vit. K3 50,62mg; vit. B12 675.00mcg; zinc 3375,00mg.

The ingredients were pelleted in a meat grinder and dried in a greenhouse with circulation and air renewal at $55^{\circ} \mathrm{C}$. The fishes were fed twice a day (around $8 \mathrm{~h}$ and 17h) to apparent satiety for a period of 90 days of experiment, being 30 days of adaptation. The siphoning of the boxes was performed every day (15h) and the water quality parameters such as $\mathrm{pH}$, oxygen, temperature and ammonia were measured weekly.After the experimental period, fish were fasted for 24 hours to empty the gastrointestinal tract. Five animals from each experimental unit were selected in order to execute biometrics, length (through pachymeter) and weight (high precision scale), for zootechnical performance data as proposed by Fracalossi and Cyrino (2013). After this, the animals were desensitized on ice and then the body composition analysis was performed. The indices were used to verify if the tested food interferes negatively or positively in the performance and health conditions of the animals. 


\subsection{Zootechnical performance}

The survival (SOB\%) - was calculated through the equation:

$$
\text { SOB }(\%)=n f / \text { ni } x 100(1)
$$

In which: $\mathrm{nf}=$ Final number of animals

ni $=$ Initial number of animals

Specific Growth Rate (SGR) - it shows the daily growth of the animals, obtained in percentage. For this calculation, the following expression was used:

$$
\text { SGR }(\% \text { days })=(\operatorname{lnpf}-\operatorname{lnpi}) / \mathrm{t} \times 100(2)
$$

ln which: ln pf $=$ Logarithm of final weight $\ln \mathrm{pi}=$ Logarithm of initial weigh

$\mathrm{t}=$ time

Hepatosomatic (HI) Index - it is the ratio between the total of the liver weight and the total of the fish weight. This index is obtained according to the following formula:

$$
\mathrm{HI}=\text { liver weight }(\mathrm{g}) / \text { fish weight }(\mathrm{g}) \times 100 \text { (3) }
$$

Weight gain (WG) - it is the final weight of the animal subtracted from the initial weight. This calculation is obtained by the following formula:

$$
\mathrm{WG}=\text { final weight }(\mathrm{g}) \text { - initial weight }(\mathrm{g})(4)
$$

Condition factor (CF) - The condition factor is the parameter that indirectly measures the physiological state of the animal, in relation to stored energy, such as hepatic glycogen and body fat. For its determination, there was used the following formula:

$$
\mathrm{CF}=\text { weight }(\mathrm{g}) / \text { total length }(\mathrm{cm})(5)
$$

Apparent feed conversion (AFD) - it is equal to the amount of food needed for the animal to gain $1 \mathrm{~kg}$ of live weight:

$\mathrm{AFD}=$ consumed diet $(\mathrm{g}) /$ (final weight - initial weight)(6)

Food Efficiency (FE) - this is the average weight gain per fish in the group, divided by the average fish feed intake. Thus, this measures the efficiency that the animal had to convert the consumed diet in live weight:

$$
\begin{gathered}
\mathrm{FE}=\text { mass gain }(\mathrm{g}) / \text { amount of the diet that were } \\
\text { ingested }(\mathrm{g}) \times 100(7)
\end{gathered}
$$

\subsection{Body composition}

Analysis of fish body composition was performed according to the standard methodology described by
INCT/ Detmann et al. (2012). They were made with the five treatments tested $\left(0 \mathrm{~g} \mathrm{~kg}^{-1}, 50 \mathrm{~g} \mathrm{~kg}^{-1}, 75 \mathrm{~g} \mathrm{~kg}^{-1}, 100 \mathrm{~g}\right.$ $\mathrm{kg}^{-1}$, and $125 \mathrm{~g} \mathrm{~kg}^{-1}$ ) of crude glycerin with 5 replicates (for each fish used).

\subsection{Hematologic parameters}

For the hematological analyzes, fifteen individuals from each treatment were randomly selected. The blood collection was performed by caudal puncture using syringes and needles bathed in Ethylenediamine TetraAcetic Acid - EDTA and then they were desensitized on ice.

Subsidiary blood samples were used immediately for the determination of hematocrit - Htc (microhematocrit technique, according to Wintrobe (1929), hemoglobin-Hb (cyanometahemoglobin method, according to Drabkin (1948) and red cell count - RBC in Neubauer's chamber using as the citrate formaldehyde as diluent.

The hematimetric indexes MCV (mean corpuscular volume), $\mathrm{MCH}$ (mean corpuscular hemoglobin) and MCHC (mean corpuscular hemoglobin concentration) were also evaluated.

For the hematimetric indexes the following formulas were used:

$$
\begin{aligned}
\operatorname{MCV}\left(\mu \mathrm{m}^{3}\right) & =(\text { Hct } \times 10) / \mathrm{RBC} \\
\mathrm{MCH}(\mathrm{pg}) & =(\mathrm{Hb} \times 10) / \mathrm{RBC} \\
\operatorname{MCHC}\left(\mathrm{d} / \mathrm{L}^{-1}\right) & =(\mathrm{HCM} \times 100 / \mathrm{VCM})
\end{aligned}
$$

Blood distension slides were made for total and differential leukocyte (Lc) counts and total thrombocyte counts (Tr) and stained with PANOTE kit, according to the methodology recommended by Ranzani-Paiva et al. (2013).

\subsection{Analyzes of biochemical parameters}

The blood was centrifuged at $3000 \mathrm{rpm}$ for 5 minutes to obtain blood plasma. The total of proteins, cholesterol, triacylglycerol, Aspartate Amino Transferase enzyme (AST) and Alanine Amino Transferase enzyme (ALT) were analyzed through the Labtest Kit and the readings in the spectrophotometry apparatus.

For the quantification of the blood glucose concentration, the One Touch Ultra2 portable reading device (reading between 20 and $600 \mathrm{mg} / \mathrm{dL}$ ) was used with disposable tapes that were suitable for the apparatus. About 1 to $5 \mu \mathrm{l}$ of blood was placed on the tape, after the monitor switched on automatically and then it was waited 5 seconds for quantification of the blood glucose concentration in $\mathrm{mg} / \mathrm{dL}$.

For the determination of hepatic and muscular glycogen this researche used the technique described by Bidinotto et al. (1997). In addition to the the referred methodology, hepatic glycogen was also analyzed using Image $\mathbf{J}$ software to quantify the total area occupied by it. 


\subsection{Histopathology of the liver and the kidney}

There were selected 9 animals (randomly) from each treatment and they were desensitized on ice to remove hepatic and renal tissue samples

The samples were washed with $0.9 \%$ saline solution and fixed for 24 hours in Bouin solution. Subsequently, the material was washed for 24 hours in running water and stored in containers containing $70 \%$ alcohol. The samples were then dehydrated in successive alcohol baths $(70 \%$, $80 \%, 90 \%, 95 \%$, and $100 \%$ ) and clarified in xylol FERNANDEZ et.al., 2011).

After the dehydration and clarification processes were completed, the samples were embedded in paraffin for histological sections of $3 \mu \mathrm{m}$ thick using a manual microtome, which were stained with Hematoxylin and Eosin (HE) for later analysis under the light microscopy. All sections were analyzed using images obtained on a LEICA DM500 microscope connected to a computer by the LAZ 2.0 program.

To identify alteration in the liver or the kidney alterations it was observed 5 fields of each slide in 100x increase. The histopathological analyzes of both tissues were evaluated by two semi-quantitative methods: Mean Value of Changes (MVC) and Histological Alterations Index (HAI).

The calculation of (MVC) results in the incidence of lesions, according to Schwaiger et al. (1997). Thus, a numerical value was assigned for each animal according to the scale: grade 1 (absence of histopathological alteration), grade 2 (occurrence of localized lesions) and grade 3 (lesions widely distributed by the organ).

To evaluate the degree of liver and kidney alterations, the Histological Alteration Index (HAI) was used according to Poleksic and Mitrovic-Tutundžic (1994), which each alteration was classified in progressive degrees related to tissue function impairment: stage I, for changes that do not compromise the functioning of the body; stage II for more severe alterations that compromise organ functioning, but are reversible; and stage III, for the most serious alterations that irreversibly compromise the functioning of the organ.

HAI value was calculated for each animal according to the formula: HAI $=(1 \mathrm{x} \Sigma \mathrm{I})+(10 \mathrm{x} \Sigma \mathrm{II})+(100 \times \Sigma \mathrm{III})$, in which $\Sigma$ I, II and III correspond to the diferent stages numbers I, II and III respectively.

The HAI values between 0 and 10 indicate normal tissue functioning; between 11 and 20 indicate mild damage to the organ; between 21 and 50 indicate moderate damage; from 51 to 99, severe damage and greater than 100 indicates irreversible tissue damage.

\subsection{Statistical analyzes}

The data were submitted to analysis of variance (ANOVA) and the averages were compared by Tukey's test $(p>0.05)$ and those without normal distribution were submitted to non-parametric analysis (Kruskall Wallis) using the Instat Program v 3.0 for Windows, also, the results were expressed as average \pm standard deviation. The parameters of performance and body composition were also submitted to linear regression analysis.

\subsection{Water analysis}

\section{RESULTS}

Regarding the environmental variables quantified during the experiment, differences between treatments were not identified $(p>0.05)$. The average values for water quality parameters that were recorded during the experimental period are displayed in (Table 2).

Table.2: Water quality parameters during the experimental period.

\section{CRUDE GLYCEROL (\%)}

\begin{tabular}{|c|c|c|c|c|c|c|}
\hline $\begin{array}{l}\text { WATER QUALITY } \\
\text { PARAMETERS }\end{array}$ & $0 \mathrm{~g} \mathrm{~kg}^{-1}$ & $50 \mathrm{~g} \mathrm{~kg}^{-1}$ & $75 \mathrm{~g} \mathrm{~kg}^{-1}$ & $100 \mathrm{~g} \mathrm{~kg}^{-1}$ & $125 \mathrm{~g} \mathrm{~kg}^{-1}$ & CV\% \\
\hline $\mathrm{pH}$ & $6,2 \pm 0,08$ & $6,2 \pm 0,09$ & $6,2 \pm 0,09$ & $6,2 \pm 0,11$ & $6,2 \pm 0,01$ & 0,25 \\
\hline $\mathrm{O}_{2}$ dis solved $(\mathrm{mg} / \mathrm{L})$ & $8,0 \pm 1,03$ & $8,0 \pm 0,99$ & $8,0 \pm 0,78$ & $8,0 \pm 0,69$ & $8,0 \pm 0,69$ & 1,96 \\
\hline Temperature $\left({ }^{\circ} \mathrm{C}\right)$ & $27,1 \pm 0,74$ & $27,0 \pm 0,63$ & $27,1 \pm 0,67$ & $27,2 \pm 0,61$ & $26,8 \pm 0,59$ & 0,22 \\
\hline Ammonia (mg/L) & 0 & 0 & 0 & 0 & 0 & - \\
\hline
\end{tabular}

The values are followed by the calcultation of the averages and standard deviation

\subsection{Zootechnical performance}

In the comparison of the zootechnical performance indexes, it was observed that there was no statistical difference between the treatments for the analyzes of the final length, final weight, survival, hepatosomatic index, condition factor, weight gain, conversion or diet efficiency.However, the animals specific growth rate was influencedby the levels of crude glycerin presenting a moderate and an increasing linear behavior compared to the control diet (Fig. 1). The zootechnical parameters of juveniles "Pintado" were analyzed in the present study and are demonstrated in (Table3). 


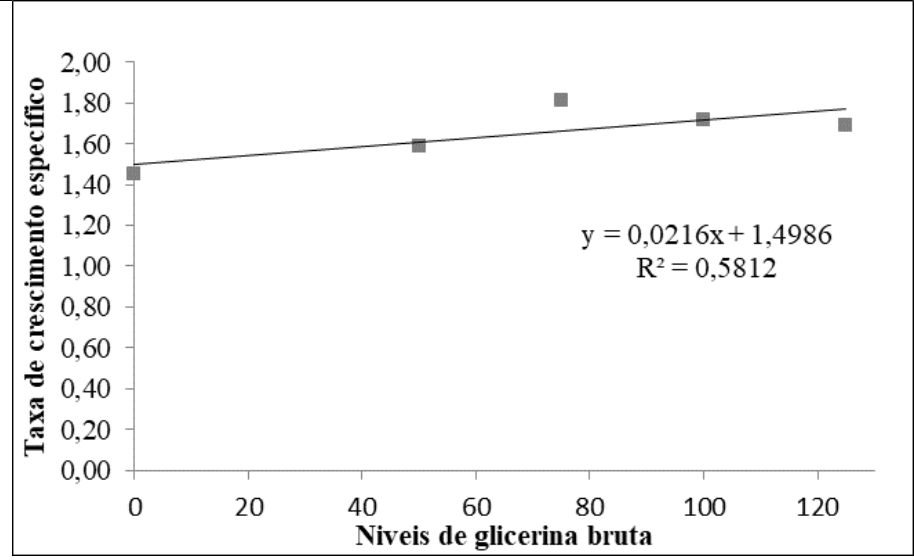

Figure. 1: linear regression of specific growth of juveniles of pintado

Table.3: Zootechnical parameters of the hybrid Amazon catfish "Pintado", that were feed with different levels of crude glycerin in the diet.

CRUDE GLYCEROL (\%)

\begin{tabular}{|c|c|c|c|c|c|c|}
\hline $\begin{array}{l}\text { ZOOTECHNICAL } \\
\text { PARAMETERS }\end{array}$ & $0 \mathrm{~g} \mathrm{~kg}^{-1}$ & $50 \mathrm{~g} \mathrm{~kg}^{-1}$ & $75 \mathrm{~g} \mathrm{~kg}^{-1}$ & $100 \mathrm{~g} \mathrm{~kg}^{-1}$ & $125 \mathrm{~g} \mathrm{~kg}^{-1}$ & CV\% \\
\hline FL (cm) & $16,66 \pm 1,35$ & $17,36 \pm 1,59$ & $18,23 \pm 0,51$ & $15,86 \pm 1,41$ & $16,83 \pm 1,25$ & 2,46 \\
\hline FW (g) & $27,66 \pm 7,00$ & $26,66 \pm 5,10$ & $35,62 \pm 3,26$ & $28,06 \pm 7,06$ & $28,73 \pm 5,34$ & 4,21 \\
\hline SOB $(\%)$ & $96,66 \pm 5,77$ & $93,33 \pm 11,54$ & $83,33 \pm 28,86$ & $96,66 \pm 5,77$ & $96,66 \pm 5,77$ & 10,71 \\
\hline SGR $(\%)^{1}$ & $1,45 \pm 0,39$ & $1,59 \pm 0,16$ & $1,81 \pm 0,39$ & $1,71 \pm 0,40$ & $1,68 \pm 0,37$ & 6,31 \\
\hline $\mathrm{HI}(\%)$ & $0,01 \pm 0,00$ & $0,01 \pm 0,01$ & $0,01 \pm 0,02$ & $0,01 \pm 0,03$ & $0,01 \pm 0,04$ & 13,06 \\
\hline $\mathrm{CF}(\mathrm{g} / \mathrm{cm})$ & $1,63 \pm 0,32$ & $1,62 \pm 0,13$ & $2,22 \pm 0,08$ & $1,75 \pm 0,28$ & $1,69 \pm 0,21$ & 5,64 \\
\hline WG (\%) & $20,20 \pm 7,44$ & $21,46 \pm 2,21$ & $33,86 \pm 2,38$ & $22,06 \pm 7,70$ & $22,33 \pm 6,42$ & 11,36 \\
\hline AFD & $2,58 \pm 0,63$ & $3,01 \pm 1,26$ & $1,72 \pm 0,19$ & $3,50 \pm 1,23$ & $2,68 \pm 0,53$ & 16,54 \\
\hline EA $(\%)$ & $4,06 \pm 1,13$ & $3,90 \pm 2,13$ & $5,84 \pm 0,72$ & $3,13 \pm 1,24$ & $4,00 \pm 1,25$ & 12,29 \\
\hline
\end{tabular}

The values are followed by the calcultation of the averages and standard deviations. Fl = final length; FW = final weight; $\mathrm{SOB}=$ survival; SGR = specific growth rate; $\mathrm{HI}=$ hepatos omatic index; $\mathrm{ICF}=$ initial condition factor; FCF $=$ final condition factor; GP = weight gain; $\mathrm{AFD}=$ apparent feed conversion; $\mathrm{FE}=$ food efficiency. ${ }^{1}$ Linear effect $\mathrm{y}=0.0216 \mathrm{x}+1.4986 \mathrm{R}^{2}=$ 0.5812 .

\subsection{Body composition}

The body composition of the pintado juveniles was not influenced by the partial replacement of maize by crude glycerin. Since no significant differences $(p>0.05)$ were found between the treatments in any of the indices analyzed.
The results of the analysis of body composition of juveniles of pintado (moisture content, ashes and crude protein) are presented in (Table 4).

Table .4: Body composition of the Amazon catfish "Pintado", that were feed with different levels of crude glycerin in the diet CRUDE GLYCEROL (\%)

\begin{tabular}{ccccccc}
\hline COMPOSITION & $\mathbf{0 ~} \mathbf{~ k g}^{-1}$ & $\mathbf{5 0} \mathbf{g ~ k g}^{-1}$ & $\mathbf{7 5} \mathbf{~ g ~ k g}$ & $\mathbf{1 0 0} \mathbf{~ g ~ k g}^{-1}$ & $\mathbf{1 2 5} \mathbf{~ g ~ k g}^{-\mathbf{1}}$ & $\mathbf{C V \%}$ \\
Moisture (\%) & $77,39 \pm 3,02$ & $73,53 \pm 6,5$ & $73,91 \pm 4,79$ & $80,68 \pm 4,27$ & $73,71 \pm 4,10$ & 1,68 \\
Ashes (\% MN) & $2,88 \pm 0,51$ & $3,85 \pm 0,96$ & $3,17 \pm 0,78$ & $2,72 \pm 0,84$ & $3,48 \pm 0,50$ & 6,28 \\
Crude Protein (\% MN) & $14,29 \pm 2,33$ & $15,30 \pm 4,47$ & $14,74 \pm 3,10$ & $12,46 \pm 1,68$ & $16,06 \pm 2,20$ & 7,44 \\
\hline
\end{tabular}

The values are followed by the calcultation of the averages and standard deviations. 
3.4 Evaluation of the red trial

The increasing levels of crude glycerin in the diet of pintados did not result in changes in the erythrocyte variables in relation to the control $(\mathrm{P}>0.05)$ : hematocrit, hemoglobin, erythrocyte cell count and hematimetric indexes (mean corpuscular volume, mean corpuscular hemoglobin and mean corpuscular hemoglobin concentration) as presented in (Table 5).

Table.5: hematimetric parameters of juveniles of pintado, that were fed with different levels of crude glycerin .

\begin{tabular}{|c|c|c|c|c|c|c|c|}
\hline \multicolumn{8}{|c|}{ CRUDE GLYCEROL (\%) } \\
\hline PARAMETERS & $0 \mathrm{~g} \mathrm{~kg}^{-1}$ & $50 \mathrm{~g} \mathrm{~kg}^{-1}$ & $75 \mathrm{~g} \mathrm{~kg}^{-1}$ & $100 \mathrm{~g} \mathrm{~kg}^{-1}$ & $125 \mathrm{~g} \mathrm{~kg}^{-1}$ & EFFECT & CV\% \\
\hline $\begin{array}{c}\mathrm{RBC} \\
\text { (milions/mm3) }\end{array}$ & $0.67 \pm 0.25$ & $0.54 \pm 0.21$ & $0.48 \pm 0.15$ & $0.69 \pm 0.28$ & $0.67 \pm 0.16$ & NS & 8,96 \\
\hline $\mathrm{Hb}(\mathrm{g} / \mathrm{dL})$ & $7.23 \pm 1.19$ & $7.30 \pm 1.84$ & $7.32 \pm 1.35$ & $7.32 \pm 1.48$ & $7.51 \pm 1.14$ & NS & 3,8 \\
\hline Hct $(\%)$ & $23.66 \pm 2.82$ & $25.26 \pm 3.26$ & $24.93 \pm 3.12$ & $24.60 \pm 3.52$ & $25.86 \pm 3.44$ & NS & 1,12 \\
\hline MCV (fL) & $333.58 \pm 142.65$ & $\begin{array}{c}389.54 \pm \\
178.59\end{array}$ & $\begin{array}{c}458.16 \pm \\
101.74\end{array}$ & $\begin{array}{c}335.73 \pm \\
113.62\end{array}$ & $\begin{array}{c}355.74 \pm \\
121.80\end{array}$ & NS & 8,05 \\
\hline $\mathrm{MCH}(\mathrm{pg})$ & 130.07. \pm 57.50 & $138.59 \pm 57.72$ & $140.56 \pm 36.67$ & $118.96 \pm 57.62$ & $136.09 \pm 46.35$ & NS & 7,12 \\
\hline MCHC (\%) & $28.35 \pm 5.03$ & $26.31 \pm 4.85$ & $28.35 \pm 6.26$ & $25.13 \pm 3.75$ & $28.50 \pm 4.16$ & NS & 3,51 \\
\hline
\end{tabular}

Values expressed as mean \pm standard deviation. $\mathrm{RBC}=$ number of erythrocytes; $\mathrm{Hb}=$ hemoglobin; Hct $=$ hematocrit; $\mathrm{MCV}$ $=$ Mean corpuscular volume; $\mathrm{MCH}=$ mean corpuscular hemoglobin; $\mathrm{Mchc}=$ Mean corpuscular hemoglobin concentration .

\subsection{Evaluation of the white trial}

The total and differential counting of leukocyte were not altered by diet, $(\mathrm{P}>0.05)$. The averages followed by the standard deviations of this count are demonstrated in (Table 6).

Table.6: Total and differential leukocyte counts of the juveniles of pintado that were fed with different levels of crude glycerin.

\section{CRUDE GLYCEROL (\%)}

\begin{tabular}{|c|c|c|c|c|c|c|c|}
\hline PARAMETERS & $0 \mathrm{~g} \mathrm{~kg}^{-1}$ & $50 \mathrm{~g} \mathrm{~kg}^{-1}$ & $75 \mathrm{~g} \mathrm{~kg}^{-1}$ & $100 \mathrm{~g} \mathrm{~kg}^{-1}$ & $125 \mathrm{~g} \mathrm{~kg}^{-1}$ & EFEITO & $\mathrm{CV} \%$ \\
\hline Thrombocytes (uL) & $22.38 \pm 29.98$ & $25.19 \pm 33.32$ & $24.96 \pm 32.57$ & $23.78 \pm 28.92$ & $23.04 \pm 27.50$ & NS & 10,25 \\
\hline Leukocytes (uL) & $\begin{array}{c}122.06 \pm \\
35.94\end{array}$ & $\begin{array}{c}139.03 \pm \\
73.49\end{array}$ & $\begin{array}{c}117.78 \pm \\
73.25\end{array}$ & $\begin{array}{c}120.92 \pm \\
51.05\end{array}$ & $\begin{array}{c}126.76 \pm \\
54.33\end{array}$ & NS & 12,75 \\
\hline Lymphocytes (\%) & $97.30 \pm 3.02$ & $97.40 \pm 2.83$ & $96.60 \pm 2.41$ & $97.90 \pm 1.66$ & $98.30 \pm 1.41$ & NS & 0,72 \\
\hline Neutrophils (\%) & $2.20 \pm 2.61$ & $2.10 \pm 2.68$ & $3.00 \pm 2.16$ & $1.50 \pm 1.71$ & $1.30 \pm 1.25$ & NS & 11,03 \\
\hline Monocytes (\%) & $0.10 \pm 0.31$ & $0.20 \pm 0.42$ & $0.10 \pm 0.31$ & $0.20 \pm 0.42$ & $0.20 \pm 0.42$ & NS & 36,08 \\
\hline *LG-PAS (\%) & $0.20 \pm 0.42$ & $0.10 \pm 0.31$ & $0.20 \pm 0.42$ & $0.20 \pm 0.42$ & $0.10 \pm 0.31$ & NS & 36,08 \\
\hline Eosinophils (\%) & $0,20 \pm 0,42$ & $0,20 \pm 0,42$ & $0,10 \pm 0,31$ & $0,20 \pm 0,63$ & $0,10 \pm 0,31$ & NS & 80,69 \\
\hline
\end{tabular}

The values were expressed as average \pm standard deviation. NS $=$ not significant for the Turkey Test $(\mathrm{P}>0.05)$ * LG-PASgranular leucocyte-PAS positive.

\subsection{Biochemical analysis}

The analysis of the hepatic glycogen did not present any statistical difference in comparison with the treatments with inclusion of glycerol in relation to the control as shown in (Table 7 and 8). The muscle glycogen analyzed in this study had a higher concentration in the control diet (0\% glycerol) when compared to the treatment with $12.5 \%$ glycerol as presented in (Table 7).

Table.7: Hepatic and muscle glycogen of the juveniles of pintado, according to the methodology o Bidinotto et al. (1997).

\begin{tabular}{|c|c|c|c|c|c|c|c|}
\hline & \multicolumn{7}{|c|}{ CRUDE GLYCEROL (\% ) } \\
\hline PARAMETERS & $0 \mathrm{~g} \mathrm{~kg}^{-1}$ & $50 \mathrm{~g} \mathrm{~kg}^{-1}$ & $75 \mathrm{~g} \mathrm{~kg}^{-1}$ & $100 \mathrm{~g} \mathrm{~kg}^{-1}$ & $125 \mathrm{~g} \mathrm{~kg}^{-1}$ & EFFECT & CV\% \\
\hline $\begin{array}{c}\text { HEPATIC } \\
\text { GLYCOGEN } \\
\text { (umoles) }\end{array}$ & $\begin{array}{c}33,76 \pm \\
10,32 \mathrm{a}\end{array}$ & $\begin{array}{c}33,29 \pm \\
11,00 \mathrm{a}\end{array}$ & $32,44 \pm 3,28 a$ & $41,42 \pm 5,44 \mathrm{a}$ & $35,66 \pm 5,82 a$ & NS & 9,44 \\
\hline
\end{tabular}




\section{MUSCLE}

GLYCOGEN

$31.88 \pm 4.86 \mathrm{a}$

$35.45 \pm 7.24 \mathrm{a}$

$24.71 \pm 7.00 \mathrm{a}$

25. $09 \pm 6.78 \mathrm{a}$

$18.03 \pm 2.73 b$

S

7,11 (umoles)

Averages on the same line, followed by distinct letters, differ ( $>>0.05)$ by the Turkey Test. The values are expressed as average \pm standard deviation. $\mathrm{NS}=$ not significant; $\mathrm{S}=$ significant.

Table.8: Hepatic glycogen of juveniles of pintado, analyzed with the Image J program.

\begin{tabular}{|c|c|c|c|c|c|c|c|}
\hline \multirow[b]{2}{*}{ PARAMETERS } & \multicolumn{7}{|c|}{ CRUDE GLYCEROL (\%) } \\
\hline & $0 \mathrm{~g} \mathrm{~kg}^{-1}$ & $50 \mathrm{~g} \mathrm{~kg}^{-1}$ & $75 \mathrm{~g} \mathrm{~kg}^{-1}$ & $100 \mathrm{~g} \mathrm{~kg}^{-1}$ & $125 \mathrm{~g} \mathrm{~kg}^{-1}$ & EFFECT & CV\% \\
\hline $\begin{array}{c}\text { HEPATIC } \\
\text { GLYCOGEN }(\%)\end{array}$ & $\begin{array}{c}33,76 \pm \\
10,32\end{array}$ & $\begin{array}{c}33,29 \pm \\
11,00\end{array}$ & $32,44 \pm 3,28$ & $41,42 \pm 5,44$ & $35,66 \pm 5,82$ & NS & 9,44 \\
\hline
\end{tabular}

The values are expressed as average \pm standard deviation. NS $=$ not significant $(\mathrm{P}>0.05)$ by the Turkey Test.

\subsection{Histopathological analysis}

\subsubsection{Liver}

The alterations observed in the liver of the pintado that were feed with the control diet and in those fed with increasing levels of crude glycerin were mostly stage I lesions, considered to be alterations that did not compromise the functioning of the organ and a stage II alteration considered more severe, but also reversible. The alterations found in hepatocytes were: nucleus at the periphery of the cell, nuclear hypertrophy, cytoplasmic vacuolization, sinusoidal dilatation and biliary stagnation. The frequency of the hepatic changes and the classification of the severity and the impairment of hepatic function found in the treatments are presented in (Table 9). The most frequent alterations found in the liver of the pintados are presented in the (Fig. 2).

Table.9: Frequency of histopathological changes in the liver of pintado juveniles that were feed with different levels of crude glycerin in the diet.

\begin{tabular}{|c|c|c|c|c|c|c|}
\hline \multirow[b]{2}{*}{ ALTERATIONS } & \multicolumn{5}{|c|}{ DIETS } & \multirow[b]{2}{*}{$125 \mathrm{~g} \mathrm{~kg}^{-1}$} \\
\hline & STAGES & $0 \mathrm{~g} \mathrm{~kg}^{-1}$ & 50 g kg-1 $^{-1}$ & $75 \mathrm{~g} \mathrm{~kg}^{-1}$ & $100 \mathrm{~g} \mathrm{~kg}^{-1}$ & \\
\hline nucleus at the periphery of the cell & I & + & + & $0+$ & $0+$ & $0+$ \\
\hline nuclear hypertrophy & I & 0 & 0 & $0+$ & $0+$ & $0+$ \\
\hline cytoplasmic vacuolization & I & 0 & 0 & $0+$ & $0+$ & $0+$ \\
\hline sinusoidal dilatation & I & 0 & $0+$ & $0+$ & 0 & 0 \\
\hline biliary stagnation & II & $0+$ & $0+$ & $0+$ & $0+$ & $0+$ \\
\hline
\end{tabular}

$0=$ nonexistent $0+=$ alterations of rare occurrence $+=$ alterations occurring; $++=$ fairly frequent alterations; $+++=$ alterations of intense occurrence

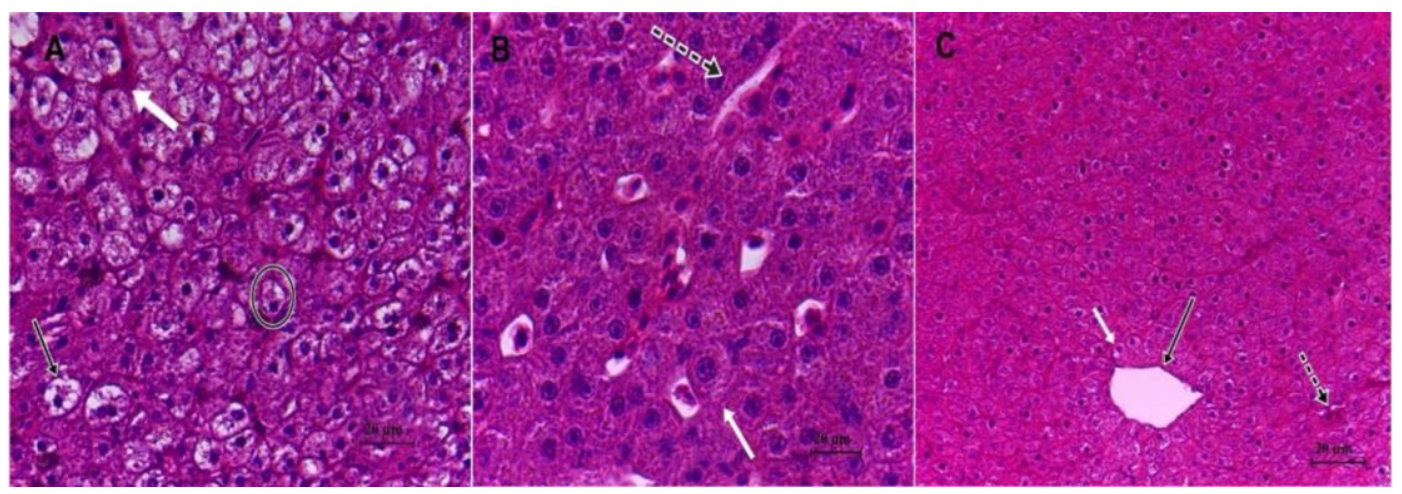

Fig.2: histopathological alterations in the liver of pintado. (A) biliary stagnation (white arrow), cytoplasmic vacuolization in hepatocytes (black arrow) and nucleus in the periphery of the cell (circular area). (B) sinusoidal dilatation (dashed black arrow) and nuclear hypertrophy (white arrow). (C) normal hepatic tissue - hepatocytes (white arrow), central vein (thin black arrow) and sinusoids (dashed black arrow). 
The results of the average value of alterations and the indexes of histopathologival changes are displayed in (Fig. 3).The Mean Value of Histological Alteration (VMA), that is obtained considering the hepatic alterations did not present significant differences ( $p>$ $0.05)$ between the experimental diets $\left(0 \mathrm{~g} \mathrm{~kg}^{-1}, 50 \mathrm{~g} \mathrm{~kg}^{-1}\right.$, $75 \mathrm{~g} \mathrm{~kg}^{-1}, 100 \mathrm{~g} \mathrm{~kg}^{1}$, and $125 \mathrm{~g} \mathrm{~kg}^{-1}$ ) and the control

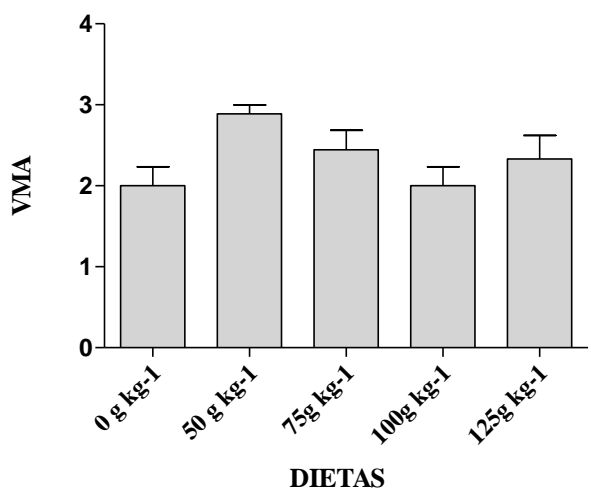

(a) (fig.3a) group. The alteration that were observed in the liver, were punctually distributed in the organ and they did not exceed grade 2. The Histological Alteration Index (HAI) also showed no significant difference (fig.3b), which demonstrates that changes in the hepatic tissue did not compromise liver functioning.

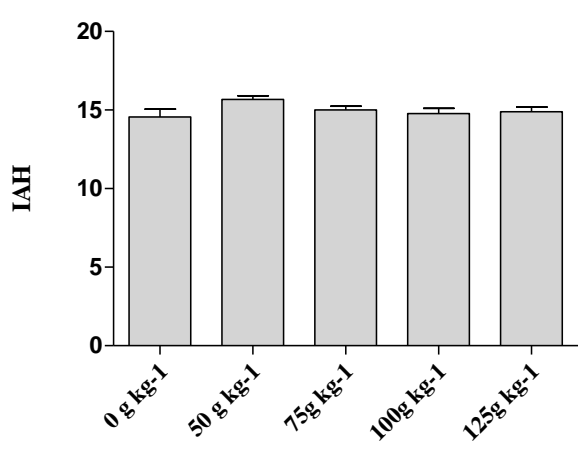

DIETAS

(b)

Fig.3: Average values of VMA and HAI in the liver of pintado. Data are the averages \pm standard deviation $(p>0,05)$.

\subsubsection{Kidney}

The renal histopathological analysis that was performed in this study showed that the alterations observed in the kidney of the juvenilles of pintado were limited to the renal tubules and were mostly stage I lesions (alterations that do not compromise the functioning of the organ) and stage II (considered more severe, but still possible to reverte).

The alteration were: nuclear hypertrophy, tubular light dilation and tubular light occlusion and are displayed in (Fig.4).
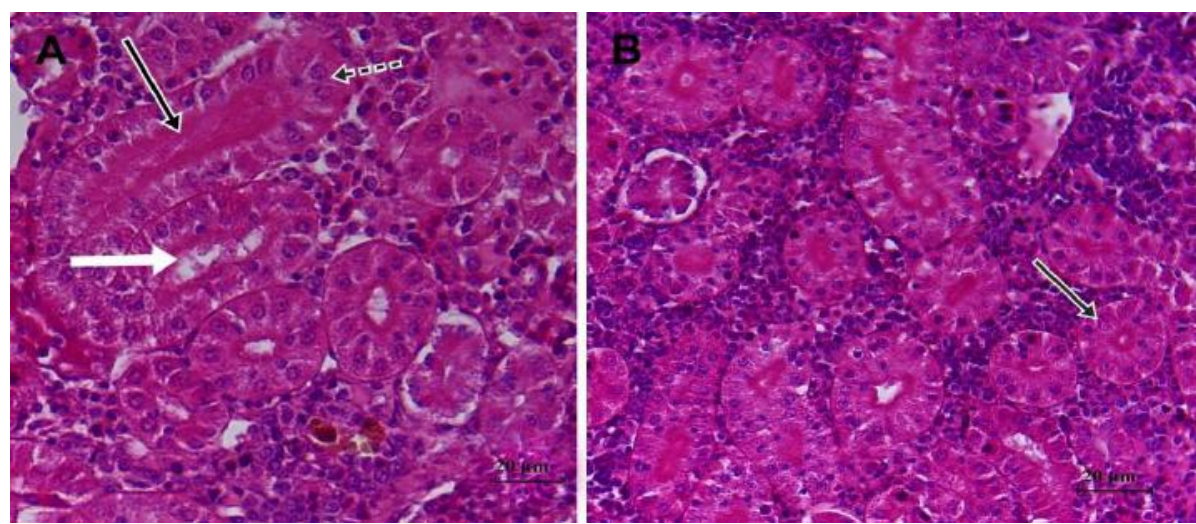

Fig.4: Histopathological changes in the pintado kidney. (A) tubular light occlusion (black arrow), tubular light dilatation (white arrow) and nuclear hypertrophy (dashed black arrow). (B) Renal tubule with normal morphology (black arrow).

The frequency of renal changes and the degree of severity and impairment of renal function found in the treatments are showed in (Table 10).
The results of the the average value of alterations and the index of histopathological changes are presented in (Fig.5). 
Table 10: Occurrence of alterations in the renal tissue of pintado juveniles that were feed with different levels of crude glycerin in the diet.

DIETS

\begin{tabular}{|c|c|c|c|c|c|c|}
\hline ALTERATIONS & STAGE & $0 \mathrm{~g} \mathrm{~kg}^{-1}$ & $50 \mathrm{~g} \mathrm{~kg}^{-1}$ & $75 \mathrm{~g} \mathrm{~kg}^{-1}$ & $100 \mathrm{~g} \mathrm{~kg}^{-1}$ & $125 \mathrm{~g} \mathrm{~kg}^{-1}$ \\
\hline nuclear hypertrophy & I & $0+$ & $0+$ & $0+$ & + & + \\
\hline tubular light dilatation & I & 0 & 0 & 0 & $0+$ & 0 \\
\hline tubular light occlusion & II & + & + & $0+$ & $0+$ & $0+$ \\
\hline
\end{tabular}

$0=$ nonexistent $0+=$ alterations of rare occurrence; $+=$ alterations occurring; $++=$ fairly frequent alterations; $+++=$ alterations of intense occurrence.

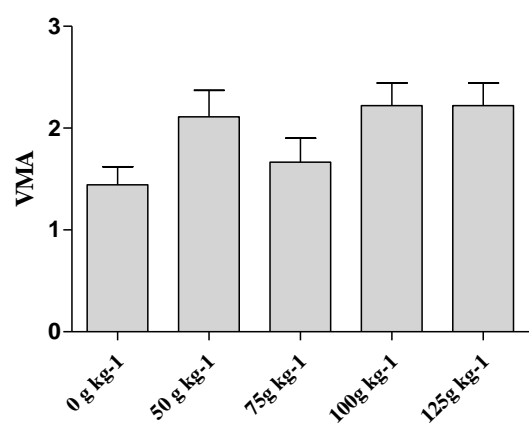

DIETAS

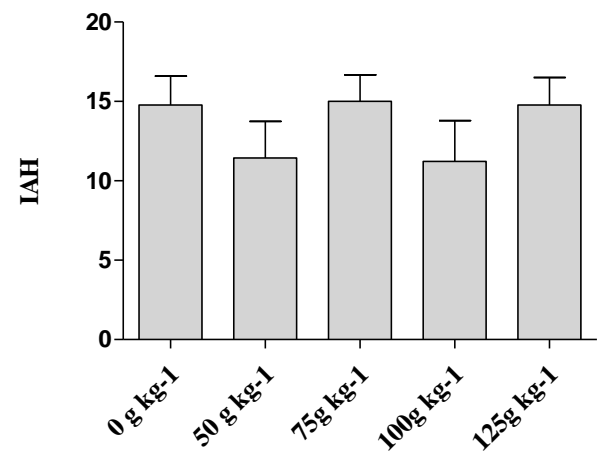

DIETAS

(a)

(b)

Fig.5: Average values of VMA and HAI in the pintado kidney. Data are the average \pm standard deviation $(p>0,05)$.

Hence, as observed in the liver analysis, the Mean Value of Histological Change (VMA) obtained for renal alterations did not present significant differences $(\mathrm{p}>$ $0.05)$ between the experimentais diets $\left(50 \mathrm{~g} \mathrm{~kg}^{-1}, 75 \mathrm{~g} \mathrm{~kg}^{-}\right.$ ${ }^{1}, 100 \mathrm{~g} \mathrm{~kg}^{1}$, and $125 \mathrm{~g} \mathrm{~kg}^{-1}$ of crude glycerin) and the control (Figure 5a) one. The alterations were distributed punctually in the renal area, because they did not exceed stage 2.

The Histological Alteration Index (HAI) also showed no significant difference (figure $5 b$ ), wich demonstrates that the renal alterations were not serious in order to compromise the functioning of the organ.

\section{DISCUSSION}

The water parameters analyzed during the experiment were not influenced by the diets tested. All the analyzed parameters were kept within the standards that are recommended for the cultivation of fish of tropical climate (CAMPOS, 2010; RODRIGUES, 2013), this result is probably linked to the constant renewal of the water.

In the comparison of the zootechnical indexes only the specific rate of growth of the animals was influenced by the levels of crude glycerin, it presented a moderate increasing of linear behavior in comparison to the control diet.

Balen et al. (2017) also observed that the SGR of Curimbatá juveniles (Prochilodus lineatus) was influeced by the crude glycerin $\left(0,40,80,120,160\right.$ e $\left.200 \mathrm{~g} \mathrm{~kg}^{-1}\right)$. In this referred study, the $40 \mathrm{~g} \mathrm{~kg}^{-1}$ diet promoted the highest values whilist in the diet of $200 \mathrm{~g} \mathrm{~kg}^{-1}$ there was the lowest values of inclusion.

Neu et al. (2013) reported that there was no difference in the growth performance of Nile tilapia juveniles that were feed different levels $\left(0,25,50,75\right.$ and $\left.100 \mathrm{~g} \mathrm{~kg}^{-1}\right)$ of dietary glycerol was observed. Li et al. (2010) showed that the use of up to $100 \mathrm{~g} \mathrm{~kg}^{-1}$ dietary glycerol for channel catfish (Ictalurus punctatus) did not cause changes in weight gain, feed efficiency, hepatosomatic index and survival. However, the inclusion of 150 and $200 \mathrm{~g} \mathrm{~kg}^{-1}$ of glycerol in the diet adversely affected its growth performance.

The length of the animals was relatively close, ranging from $15.86 \mathrm{~cm}$ to $18.23 \mathrm{~cm}$ in treatments with $100 \mathrm{~g} \mathrm{~kg}^{-1}$ inclusion of glycerol and with $75 \mathrm{~g} \mathrm{~kg}^{-1}$ addition of the product, respectively. One factor that may have influenced the non- statistical differentiation of the values of length and final weight is that the fish of the current 
study received, even with the increasing levels of crude glycerin in the diets, isoproteic and isoenergetic diets.

In the present study the survival rate in all diets tested was greater than $80 \%$. These results were close to the values described by Gonçalves et al. (2015) and Moesch et al. (2016) for juveniles of Nile tilapia fed with increasing levels of glycerol.

However, in contrast to this result Neu et al. (2012) found that the survival of Nile tilapia (Oreochromis niloticus) fingerlings was higher in treatment that did not contain glycerol. The highest mortality rates according to the author were at the two lowest levels tested, the $75 \mathrm{~g}$ $\mathrm{kg}^{1}$ followed by the $25 \mathrm{~g} \mathrm{~kg}^{-1}$. Therefore, differences species and developmental phases may influence the response of the animal metabolism to adapt to glycerol in the diet.

According to the referred author, the development phase of the animals used in the research may have been preponderant for a high mortality rate, however, other factors may have contributed to this occurrence, among them, the temperature and the tested food source itself.

Hepatosomatic index can be altered given the great importance of energetic metabolism in fish liver, since hepatic deposition of lipids as well as glycogen is common. However, in the present study, this index did not present any alterations in the metabolic functions of the liver, even in comparison to the differents levels of crude glycerin. Moesch et al. (2016) when testing the influence and the best level of replacement of maize by crude glycerol $\left(0,200,400,600,800\right.$ and $\left.1000 \mathrm{~g} \mathrm{~kg}^{-1}\right)$ in diets for Nile tilapia fingerlings, observed a significant difference for the hepatosomatic index.

The condition factor consists in a important indicator of the degree of hygiene of an individual, where its value reflects the recent nutritional conditions and/or the expenses of the reserves in cyclical activities, making it possible to relate it to the environmental conditions and to the behavioral aspects of the species (GOMIERO et al., 2010).

This parameter was not influenced by the diet tested in this study, considering that there was no significant difference between the treatments. Neu et al. (2013) also did not identify a significant difference in the condition factor of juveniles of Nile tilapia (Oreochromis niloticus) fed with different levels of glycerol.

In relation to the weight gain, it did not show any variation between the treatments ( $p>0.05$ ). This result corroborates with what was described by Matos et al. (2016) and Neu et al. (2012) who also did not verify change in this variable for Tambaqui and Nile tilapia, respectively. However, Balen et al. (2017) observed an influence of dietary glycerin levels on the weight gain of juveniles of $P$. lineatus, these authors reported that as the inclusion levels of crude glycerin increased, weight gain decreased for the referred species.

Thus, as the results found by Matos (2016), the conversion and feed efficiency analyzed in this work were not influenced by the diets analyzed. Neu et al. (2012), although they did not verified statistical differences for AFE, they had observed that these values were considerably higher for Tilapia in the larval phase, which means that depending on the environmental conditions or the physiological phase in which the species is, this parameter can be influenced.

Crude glycerin has also been studied in other monogastric species and the results found in these studies are in agreement with those found in the present research. Berenchtein et al. (2010) concluded that glycerol can be used as an energy ingredient in the diet for growing and finishing pigs at levels of up to $90 \mathrm{~g} \mathrm{~kg}^{-1}$, as it did not influence performance, carcass characteristics and meat quality.

Freitas et al. (2017), when analyzing the glycerin in the broiler diet, observed that the glycerin can be added up to the $50 \mathrm{~g} \mathrm{~kg}^{-1}$ level without causing effects on the performance, litter humidity and carcass yield.

The body composition of the juveniles of pintado was not influenced by the partial replacement of maize by crude glycerin. Thus, as in the study of Neu et al. (2013), the study in the body evaluation of juveniles of Nile tilapia fed with crude glycerol did not verify statistical differences ( $p>0.05$ ) for moisture, ashes and crude protein. However, lipid deposition was influenced by the diet containing glycerol, where they presented the highest values in fish fed with $50 \mathrm{~g} \mathrm{~kg}^{-1}$ of glycerol and the lowests in fishes that were fed with $100 \mathrm{~g} \mathrm{~kg}^{-1}$.

Moesch et al. (2016) observed in Nile tilapia fingerlings fed with crude glycerol an increase in protein deposition and moisture of the whole body and the decrease of mineral matter and ethereal extract, which presented a minimum value in $720 \mathrm{~g} \mathrm{~kg}^{-1}$ substitution.

The mentioned authors point out that the higher deposition of protein and the lower deposition of lipids confirms the effects of glycerol on energy metabolism. Because the use of carbohydrates and lipids is intensified as a source of energy resulting in the saving of dietary protein, which can be deposited in the body tissues of the fish. However, the decrease in the mineral matter content would be due to the fact that the carcass analyzes were carried out using the whole fish, influencing the mineral matter levels of the body composition. The humidity in turn, even though it presented an increase in its content, remained within the range observed by other authors.

In other monogastrics animals such as finishing pigs, Melo et al. (2014) found that crude glycerin (50, 100, 150 and $200 \mathrm{~g} / \mathrm{kg}^{-1}$ ) did not influence moisture, ash, protein. In 
ruminants, Lage et al. (2009) observed that despite the different levels of crude glycerin $(0,30,60,90$ and $120 \mathrm{~g}$ $\mathrm{kg}^{-1}$ ) in the finishing lamb diet it did not influence moisture and ash contents and crude protein levels were reduced.

Analysis of the hematimetric indexes is usually used in the control of pathologies and stress, in addition to being able to demonstrate the physiological state of the animal (SILVA et al., 2012).

The concentration of erythrocytes (red blood cells) found in the present study ranged from 0.48 to 0.69 (million $/ \mathrm{mm}^{3}$ ) between treatments. These values were higher than those found by Lundstedt (2003) when testing different levels of protein and energy in the diets of juveniles of pintado (Pseudoplatystoma corruscans) measuring $21.8 \pm 0.7 \mathrm{~cm}$, where erythrocytes ranged from 0.27-0, 30 (million $/ \mathrm{mm}^{3}$ ). However, it must be considered that individuals with different sizes release energy in different amounts according to their length, and this may interfere in their hematological characteristics (RANZANI-PAIVA; TAVARES-DIAS, 2002).

The average values of hemoglobin-Hb that were found (7.23 to $7.51 \mathrm{~g} / \mathrm{dL}$ ) were within the range established by Weiss et al. (2010) which is 5 to $10 \mathrm{~g} / \mathrm{dL}$, they are lower when compared to the concentration of $\mathrm{Hb}$ in mammals. Tavares-Dias et al. when studying hybrid fishes of the genus Pseudoplatystoma ( $P$. fasciatum $x$ P. coruscans) that were from 568.0 to $1350 \mathrm{~g}$ of weight, found a range between 5.2 and $6.1 \mathrm{~g} / \mathrm{dL}$ of hemoglobin. While, Fagundes and Urbinati et al. (2008), when evaluating the hemoglobin concentration of $P$. coruscans with average weight of 14.04, 24.94 and $44.78 \mathrm{~g}$, had observed average values of $10.50 ; 8.01$ and $10.10 \mathrm{~g} / \mathrm{dL}$ respectively.

Hematocrit (globular volume) corresponds to the volume occupied by erythrocytes contained in a certain amount of the whole blood, and low values may indicate anemia. The percentage of hematocrit analyzed in this study ranged from 23.66 to $25.86 \%$ and remained within the range predicted by Weiss et al. (2010) for fish, which is 20 to $45 \%$. The values referenced by Razani-Paiva et al. (2000a, 2000b) for captive Pseudoplatystoma fasciatum (23.0-32.5\%) and for wild-type Pseudoplatystoma corruscans $(26.0 \%)$ remained close to the results described in this study.

The mean corpuscular volume (MCV) is related to cardiac dynamics and blood flow (FRIES et al., 2013). The range of MCV for fish predicted by Weiss et al. (2010), ranges from 150 to $350 \mathrm{fL}$. Although this parameter in the present study distinguished from the range of the mentioned author, it did not present a significant difference between the treatments. TavaresDias et al. (2009), cites a range of (159.2-180.3fL) for hybrids of the genus Pseudoplatystoma ( $P$. fasciatum $x P$. coruscans). While Razani-Paiva et al. (2000a) and (2000c) cite the values of (129.1-189.0 fL) and (165.2 fL); respectively

$\mathrm{MCH}$ varies considerably between species, ranging from 30 to $100 \mathrm{pg}$ (picograms) due to differences in the size of circulating globules (WEISS et al., 2010). In this study the identified $\mathrm{MCH}$ (mean corpuscular hemoglobin) was higher than those referenced by Weiss et al. (2010), however there was no statistical difference between treatments.

The distinction between the values found for VCM and $\mathrm{MCH}$ results is due to the peculiarities of fish erythrograms, since hematological parameters can be influenced by numerous factors, such as age, species, stress, temperature, photoperiod, nutritional status and the methodology used for (PEDRO et al., 2004), and they may present different values even for animals belonging to the same genus (TAVARES-DIAS, MORAES, 2004). Moreover, according to McCarthy et al. (1973), the values of VCM and $\mathrm{MCH}$ of fish require caution in their interpretation, since they are calculated from the total erythrocyte count, in which it may present a certain range of variation. However, MCHC is considered more accurate since it is calculated from the percentage of hematocrit and hemoglobin.

The average values of MCHC (25.13 a $28.50 \mathrm{~g} / \mathrm{dL})$ were in the range estabilished by Weiss et al. (2010) ehich is from 18.0 to $30.0 \mathrm{~g} / \mathrm{dL}$. According to Tavares-Dias et al., (2009) for hybrid fishes ( $P$. fasciatum $x$ P. coruscans), weighing between 568 and $1350 \mathrm{~g}$ range of $16.8-18.8 \mathrm{~g} / \mathrm{dL}$ to $\mathrm{MCHC}$

Total and differential counting of leukocyte were not altered by diet. Leukocytes are cells that play an important role in nonspecific immunity and their indices are determinant in the evaluation of fish health status (ISHIKAWA et al., 2008).

The average values of the number of leukocytes and thrombocytes from pintado juvenilles were different in comparison to the values reported for healthy hybrid Surubins (Pseudoplatystoma reticulatum $x$ P. corruscans) (PÁDUA et al., 2009), however, lymphocytes and neutrophils were the most frequent leukocytes in both species.

Tomaz and Campos (2011), studying the defense cells of Pseudoplatystoma reticulatum males and females during their reproductive period in pisciculture, reported averages for lymphocytes $(74.2 \pm 12.7$-males and $76.1 \pm$ 9.91- female) lower than those found in the present study. The average values for eosinophils $(3.63 \pm 3.09$ - male and $2.80 \pm 3.09$ - female), monocytes $(1.75 \pm 3.46$ - male and $1.30 \pm 0.86$ - female), leukocyte-PAS-positive/LGPAS $(0.68 \pm 0.250 .82$ - male \pm 0.52 -female $)$ and 
neutrophils (14.6 \pm 8.30 - male and $11.8 \pm 8.22$ - female) were larger than those reported for the Pintado.

Knowledge about the origin and development of thrombocytes and leukocytes in fish is considered scarce, although some ideas have been proposed since the beginning of the last century. However, the data acquired through the studies of hematology and/or hematopoietic organs are still inconclusive. However, organic defense blood cells present interspecific variation (TAVARESDIAS et al., 2002), which may explain the variation in the values compared above.

In addition, differential leukocyte count has some barriers that make it difficult to compare results among different authors, even for studies that use the same species. Among the problems faced are the divergence of terminology, mainly involving granulocytes and the diversity of techniques for quantification and identification of leukocytes (TAVARES-DIAS \&\& MORAES, 2004). However, leukogram is considered an important tool in the understanding of infections and other processes of homeostatic imbalance (SILVA et al., 2012).

The biochemical parameters analyzed in this study were not altered by the different levels of crude glycerin. The biochemical composition of the blood reliably portrays the constancy between ingress, egress, and metabolization of nutrients in animal tissue. This balance is termed homeostasis, in which complex metabolic-hormonal mechanisms are involved (BOCKOR, 2010).

The concentrations of total cholesterol were not affected by the inclusion of crude glycerin in the diet, corroborating with Balen (2017) results for juveniles of Curimbatá (Prochilodus lineatus), that were feed diets containing crude glycerin (0, 40, 80, 120, 160 and $200 \mathrm{~g}$ $\mathrm{kg}^{-1}$ ) and Neu et al. (2013) for juveniles of Nile tilapia with diets containing $\left(0,0,25,50,75\right.$ and $\left.100 \mathrm{~g} \mathrm{~kg}^{-1}\right)$ glycerol.

Enzymes ALT (alanine aminotransferase) and AST (aspartate aminotransferase) also had not presented a significant difference between the treatments, demonstrating that the diet did not alter their activities. These enzymes are considered important in the diagnosis of hepatic lesions, since the increase of their serum activity may be related to hepatocyte rupture, resulting from processes such as cellular necrosis or aggression by toxic agents (HARZER et al., 2015).

Total protein values found in this work did not differ much from those found by Costa et al. (2015) for Nile Tilapia, that remained between 3.93 to 4.13 and that also did not present significant difference. According to this same author, the diet containing glycerol protects protein catabolism for energy purposes in Nile tilapia. Corroborating with this study, Menton et al. (1986) also found no significant difference in plasma protein concentration of trout that were fed diets containing 60 and $120 \mathrm{~g} \mathrm{~kg}^{-1}$ glycerol.

Glucose acts as an energetic substrate stored in the form of hepatic and muscular glycogen (through glycogenesis) and can be mobilized to provide energetic support to fish. Plasma glucose is highly variable not only among species, but also interspecifically, at different stages of life or under certain feeding diets (HEMRE et al., 2002).

The results for glucose found in this research were not altered with the inclusion levels of crude glycerol in the diet. Distinguishing from the results found in this work for glucose concentration, Li et al. (2010) observed that the level of glucose in the blood of the catfish of the channel (Ictalurus punctatus) was influenced by the different levels of glycerol $(0,50,100,150$ and $200 \mathrm{~g} \mathrm{~kg}$ $\left.{ }^{1}\right)$. The values were significantly higher in fish fed with 0 $\mathrm{g} \mathrm{kg}^{-1}$ and $50 \mathrm{~g} \mathrm{~kg}^{-1}$ of glycerol than in fish fed with the other diets. Also, at levels containing 100, 150 and $200 \mathrm{~g}$ $\mathrm{kg}^{-1}$ of glycerol, glucose generally decreased

For Nile tilapia in the growth/fattening phase Moesch et al. (2016) found that glycerol-containing treatments (200, 400, 600, 800 and $1000 \mathrm{~g} \mathrm{~kg}^{-1}$ ) had the lowest blood glucose levels, a fact that the author associated with the reduction of starch (corn) in the diet.

Carnivorous fishes use lipids efficiently as a source of energy, due to the restricted ability of their metabolism to regulate glycemia (CASERAS et al., 2002; HEMRE et al., 2002), where triacylglycerols are the main form of storage of body energy in these animals

The results for the concentration of triglycerides observed in this study are similar to those obtained by Costa et al. (2015) and Neu et al. (2013). Both found that dietary glycerol levels did not influence the plasma triglyceride concentration in juvenile Nile tilapia. Costa et al. (2015) stated that there was no change in plasma triglyceride levels because there was no energy deficiency in the animal and therefore, there was no need for the species to mobilize energy and consequently to perform lipolysis on adipocytes.

Crude glycerin has been tested in a diet of other monogastric species. Romano et al. (2014) studied the effects of glycerol on the metabolism of broilers. Similarly to the present study, there was no significant difference in total cholesterol concentrations between the control group and the groups that received diets with different glycerin inclusion levels $(25,50,75$ and $100 \mathrm{~g}$ $\mathrm{kg}^{-1}$ ),

Gallego et al. (2014), when testing levels (0.0, 35, 70, 105 and $140 \mathrm{~g} \mathrm{~kg}^{-1}$ ) of semipurified glycerin neutralized in the diet, observed that the plasma glucose, cholesterol and triglycerides levels had also no effect of the inclusion of glycerin. 
In ruminant animals, Maciel et al. (2016) analyzed the performance and carcass characteristics of dairy cows that were fed diets containing crude glycerin and observed that it did not alter serum glucose concentrations, triacylglycerol, total cholesterol, high density lipoprotein cholesterol and creatinine.

Ribeiro (2015) when studying crude glycerin (0, 70, 140, and $210 \mathrm{~g} \mathrm{~kg}^{-1}$ ) in the diet of confined lamb, observed no significant difference for albumin, globulin, triglycerides, alanine aminotransferase (ALT), aspartate aminotransferase (AST) and gamma glutamyltransferase. However, serum concentrations of urea and glucose decreased linearly with the increasing of inclusion and cholesterol presented increasing linear behavior, therefore, they were influenced by glycerol.

Glycogen levels present in the hepatic tissue are adaptable to diet (SHEMU, 1997; HEMRE et al., 2002). Hepatic glycogen did not present statistical difference with the treatments with inclusion of glycerol in relation to the control. Menton et al. (1986), when examining glycerol (ranging from 10 to $120 \mathrm{~g} \mathrm{~kg}^{-1}$ ) in the diet of rainbow trout (Oncorhynchus mykiss) replacing part of wheat bran, observed that in diets containing 60 and $120 \mathrm{~g} \mathrm{~kg}^{-1}$ of glycerol there was an increase in the level of plasma glucose, but the hepatic glycogen concentration was not altered.

The concentration of muscle glycogen was higher in the control diet ( $0 \mathrm{~g} \mathrm{~kg}^{-1}$ glycerol) when compared to the treatment with $125 \mathrm{~g} \mathrm{~kg}^{-1}$ glycerol

It is well known that muscle glycogen is essential only for muscle and that its metabolization provides energy for muscle contraction, whereas hepatic glycogen regulates glycemia and provides energetic substrate for other tissues.

Silva et al. (2012), when testing two levels of glycerol (0 and $50 \mathrm{~g} \mathrm{~kg}^{-1}$ ) supplementation, as a way of replacing the muscular glycogen reserves of gilthead (Sparus aurata), observed that fish that were feed the inclusion of $50 \mathrm{~g} \mathrm{~kg} 1$ crude glycerol showed a significantly higher glycogen deposition than the control $\left(0 \mathrm{~g} \mathrm{~kg}^{-1}\right)$ group.

In previous studies involving glycerol, it has been shown that glycerol may also influence lipogenic activity. Lin (1977), when studying the addition of $200 \mathrm{~g} \mathrm{~kg}^{-1}$ glycerol in the diet of rats for three weeks, reports that it caused an increase in liver weight. On the other hand, when the same author studied $200 \mathrm{~g} \mathrm{~kg}^{-1}$ of glycerol in the diet of broilers fed for three weeks, he did not observe alteration in liver weight

Lin (1977), when studying the feeding of non-ruminant animals, observed that glycerol causes species-specific and organ-specific responses. Based on this hypothesis, in the literature, glycogen deposition and lipogenic activity can be influenced by dietary glycerol. It suggests that more studies have to be done with this food in order to uncover the metabolic effects of glycerol on energy reserves in fish.

Crude glycerin may have methanol concentrations in its constitution and that an acute intoxication by this residue can lead to the accumulation of formic acid, resulting in a process of metabolic acidosis (LAMMERS et al., 2008). In this way it is of great importance studies that investigate pathological alterations linked to the glycerol. The liver is an important organ in the digestion and absorption of nutrients from food and, therefore, the monitoring of this organ is considered essential (RAŠKOVIÉ et al., 2011). Morphological changes in the liver can be triggered by chemicals, drugs and even by unbalanced nutrition, which can result in adaptations, injury and even cell death. This organ is highly susceptible to changes in the nutritional status of fish, where diet quality interferes directly with functional histo-morph structure (HONORATO et al., 2014).

The alterations observed in the liver of the pintados that were feed on the control diet and those that were feed with increasing levels of crude glycerin were considered to be mostly alterations that did not compromise organ function.

Research on the histopathology of animals that were feed with crude glycerin are still incipient. However, even there is just a few studies performed the results corroborate with those found in the present study. Moesch et al. (2016) when studying the replacement of corn bran by crude glycerol in diets for $O$. niloticus fingerlings at concentrations of $\left(0,200,400,600,800\right.$ and $\left.1000 \mathrm{~g} \mathrm{~kg}^{-1}\right)$ concluded that there were no differences in the area of hepatocytes and that the possible toxic compounds present in the crude glycerol composition did not affect the area of hepatocytes.

According to Lammers et al. (2008) growing pigs fed with the addition of up to $100 \mathrm{~g} \mathrm{~kg}^{-1}$ glycerol in the diet had not suffered hepatic damage, since the frequency of histological lesions was not influenced by dietary treatment.

Also, in studies with ruminants, Leão et al. (2012) did not identify hepatic alterations in samples from cull cows and heifers that were feed with up to $240 \mathrm{~g} \mathrm{~kg}^{-1}$ inclusion of glycerol. As in the liver histopathological analysis, the renal lesions performed in this study, renal, were not serious in order to compromise the functioning of the organ.

Which also happened in the liver histopathological analysis of this study, the renal lesions performed were not serious in order to compromise the functioning of the organ.

There was no studies that associate the renal histology of fish with the diet containing crude glycerin. However, 
there are some reports for other monogas tric species such as swine, for example, in which there was no frequency of histological lesions in the kidney (LAMMERS, et al., 2008). In ruminants, Leão et al. (2012) also had not observed pathological alterations in the renal samples of cattle fed with crude glycerin.

\section{CONCLUSION}

The juveniles of Amazon catfish "Pintado" are able to metabolize crude glycerin up to the level of $100 \mathrm{~g} \mathrm{~kg}^{-1}$. Considering that, up to this level, no significant alterations were observed in the zootechnical parameters, body composition, hematological, biochemical and histological parameters of the animal.

\section{ACKNOWLEDGEMENT}

The researchers are honored and grateful for the financial support provided to the project, funded by the Coordination for the Improvement of Higher Education Personnel (Capes).

\section{REFERENCES}

[1] Balen, R. E., Junior, G. B., Colpini, L. M. S., Bombardelli, R. A., Silva, L.C. R.,\& Fábio Meurer. (2017).Digestible energy and inclusion of crude glycerin in diets for curimbatá juveniles.Fishing Institute Bulletin.(Doi: 10.20950/16782305.2017v43n3p347). São Paulo, v. 43, n. 3, p. 347357.

[2] Berenchtein, B., Costa, L. B., Braz, D.B., Almeida, V. V., Tse, M. L. P.,\&Miyada, V. S. (2010). Glycerol use of in the diet of growing and finishing pigs. Brazilian Journal of Animal Science. (Doi: 10.1590/S1516-35982010000700014) v.39, n.7, p.1491-1496.

[3] Bidinotto, P. M., Moraes, G.,\& Souza, R. H. S. (1997). Hepatic glycogen and glucose in eight tropical fresh water teleost fish: a procedure for field determinations of microsamples. CEPTA technical bulletin, Pirassununga, v. 10, p. 53-60.

[4] Bockor, L. (2010).Status Biochemical Indicators Nutritional. In: Seminar on Biochemistry of animal tissue. Postgraduate Program in Veterinary Science, Federal University of Rio Grande do Sul. Retrieved from:https://www.ufrgs.br/lacvet/restrito/pdf/indicad ores_nutri_luciane.pdf.

[5] Campos, J.L. Growth of Pintado, Pseudoplatystoma corruscans (Spix and Agassiz, 1829), other species of the genus Pseudoplatystoma and its hybrids. In: Baldisserotto, B.;Gomes, L. C. (Eds.) (2010). Espécies nativas para piscicultura no Brasil. Santa Maria: UFSM, $2^{\mathrm{a} e d ., ~ p . ~ 335-361 . ~}$
[6] Caseras, A., Metón, I., Vives, C., Egea, M., Fernández, F., \& Baanante, I. V. Nutritional regulation of glucose-6-phosphatase gene expression in liver of the gilthead sea bream (Sparus aurata). (2002). British Journal of Nutrition, Cambridge, v. 88, n. 6, p. 607-614.

[7] Costa, D. V., Paulino, R.R., Okamura, D., Oliveira, M.M.,\&Rosa, P.V. Growth and energy metabolism of Nile tilapia juveniles fed glycerol. (2015).Brazilian agricultural research. v.50 n. 5.

[8] Detmann, E., Souza, M. A.,Valadares Filho, S. C., Queiroz, A. C., Berchielli, T. T., Saliba, E. O. S., Cabral, L. S., Pina, D. S., Ladeira, M. M., \&Azevedo, J. A. G. Methods for food analysis - INCT - Animal Science. (2012.). Visconde do Rio Branco: Suprema.

[9] Drabkin, D. The standardization of hemoglobin measurement. (1948).American Journal of Medical Science, v. 215, n. 1, p. 110-111.

[10] Fagundes, M., \& Urbinati, E.C. Stress in pintado (Pseudoplatystoma corruscans) during farming procedures. (2008). Aquaculture, v.276, p.112-119.

[11] Fernandez, W. S., Dias, J. F., Ribeiro, C. A. O., \& Azevedo, J. S. Liver Damages and nuclear abnormalities In Erythrocytes of Atherinella Brasiliensis 104 (Actynopterigii, Atherinopsidade) from two beaches In Southeast of Brazil. (2011).Brazilian Journal of Oceanography. v. 59, n. 2, p. 163-169.

[12] Fracaloss, D. M., \& Cyrino, J. E. P. Nutriaqua Nutrition and feeding of species of interest for Brazilian aquaculture (2013). Florianópolis: Brazilian Society of Aquaculture and Aquatic Biology, 1 ed., $375 \mathrm{p}$.

[13] Freitas, L. W., Menten, J. F. M., Zavarize, K. C, Pereira, R., Romano, G. G., Lima, M. B., \& Dias, C. T. S. Evaluation of Dietary Glycerin Inclusion During Different Broiler Rearing Phases. (2017).Brazilian Journal of Poultry Science, Campinas, v. 19, p. 91-96.

[14] Fries, E.M., Zaminhan, M., LuchesI, J.D., Costa, J.M., Maluf, M.L.F., Signor, A., Boscolo, W.R.,\&Feiden, A. Características hematológicas de Carassius auratus* Hematologic characteristics of Carassius auratus. (2013).Brazilian Journal of Veterinary Science, v. 20, n. 2, p. 84-88.

[15] Gallego, A.G., Moreira, I., Pozza, P. C., Carvalho, P. L.O., Sierra, L. M. P., \& Filho, C. L. C. Neutral semipurified glycerin in starting pigs feeding. (2014).Semina: Agrarian Sciences,Londrina, v. 35, n. 5, p. 2831-2842.

[16] Gomiero, L. M., Villares-Junior, G. A., \& Braga F. M. S. Weight-length relationship and condition factor of Oligosarcus hepsetus (Cuvier, 1829) in the Serra 
do Mar State Park - Santa Virgínia Nucleus, Atlantic Forest, state of São Paulo, Brazil. (2010)Biota Neotropica, v. 10, n. 1, p. 101-105.

[17] Gonçalves, L. U. Cerozi, B.S., Silva, T. S. C., Zanon, R. B., \& Cyrino, J.E.P. Crude glycerin as dietary energy source for Nile tilapia. (2015.) Aquaculture, Amsterdam, v. 437, p. 230-234.

[18] Harzer, B., Stipp, M.C.,\&Herrerias, T. Evaluation of hepatic function of Rhamdia quelen fish exposed to the endocrine disruptors estriol and estrone. (2015).Intertox-EcoAdvisor Magazine of Toxicology Environmental Risk and Society, v. 8, n. 1, p. 82-99.

[19] Hemre, G.I., Mommsen, T.P., KrogdahL, A. Carbohydrates in fish nutrition: effects on growth, glucose metabolism and hepatic enzymes. (2002.). Aquaculture Nutrition, 8, 175-194.

[20] Honorato, C.A., Cruz, C., Carneiro, D.J., Machado, M.RF., Nascimento, C.A. Saturnino, K.C. Histology of the liver of Nile tilapia (Oreochromis niloticus) fed diets containing biological fish silage. (2014).Brazilian Veterinary Research,v.34 supl.1 Rio de Janeiro.

[21] Lammers, P. J., Kerr, B. J., Weber, T. E., Bregendahl, K., Lonergan, S. M., Prusa, K. J., Ahn, D. U., Stoffegren, W. C., \& Honeyman, M. S. Growth performance, carcass characteristics, meat quality, and tissue histology of growing pigs fed crude glycerin supplemented diets. (2008).Journal of Animal Science, v.86, p.2962-2970.

[22] Lage, J. F, Paulino, P. V. R., Pereira, L. G. R., Monnerat, J. P.I. S., Souza, N. K. P., \& Filho, S.C.V. Chemical composition of lambs fed with crude glycerin in the finishing phase. (2009). In: 46th Annual Meeting of the Brazilian Zootechny Society, Maringá-PR, UEM.

[23] Leao, J.P., Ramos, A.T.; Maruo, V.M., Souza, D.P.M., Neiva, J.N.M., Restle, J., \& Moron, S.E.Anatomopathology of bovine samples fed with glycerol. (2012).Rural Science, Santa Maria, v. 42, n. 7, p. 1253-1256.

[24] Li, M.H., Minchew, C.D., Oberle, D.F., \&Robinson, E.H. Evaluation of glycerol from biodiesel production as a feed ingredient for Channel catfish, Ictalurus punctatus. (2010)Journal of the World Aquaculture Society, Baton Rouge, v.41, n.1, p.130136.

[25] Lundstedt, L.M. Adaptive aspects of the digestive and metabolic processes of juveniles pintados (Pseudoplatystoma corruscans) with different levels of protein and energy.(2003). 140 p. Tese (Doutorado) - Universidade Federal de São Carlos .

[26] Maciel, R.P, Neiva, J. N. M, Restle, J., Miotto, F. R. C., Sousa, L.F., Cunha, O. F. R., Moron, S. E,
Parente, R. R. P. Performance and carcass characteristics of dairy steers fed diets containing crude glycerin. (2016).Brazilian Journal of Animal Science (Online), v. 45, p. 677-685.

[27] Matos, P.R., Ramos, A.T., \& Moron, S.E. Crude glycerin in diets of tambaqui juveniles. (2016.)Brazilian Archives of Veterinary Medicine and Zootechnics, v.68, n.6, p.1705-1712.

[28] Melo, D.S., Faria, P.B., Cantarelli, V.S., Rocha, M.F.M., Pinto, A.M.B.G., \& Ramos, E.M. Quality of pork meat with the use of glycerin in feeding diet. (2014).Brazilian Archives of Veterinary Medicine and Zootechnics, v.66, n.2, p.583-592.

[29] Menton, D. J., Slinger, S. J., Hilton, J. W. Utilization of free glycerol as a source of dietary energy in rainbow trout (Salmo gairdneri). (1986). Aquaculture, Amsterdam, v. 56, n. 2, p. 215-227.

[30] Moesch, A., Volkweis, M.I., Carneiro, Z.W. F., Silva, L.C.R., \& Santos, L.D. Growth, body composition and hepatopancreas morphology of Nile tilapia fingerlings fed crude glycerol as a replacement for maize in diets.(2016). Animal Feed Science and Technology, v.219, p.122 - 131.

[31] Neu, D.H., Furuya, W.M., Boscolo, W.R., Potrich, F.R., Lui, T.A., \& Feiden, A. Glycerol inclusion in the diet of Nile tilapia (Oreochromis niloticus) juveniles.(2013).Aquaculture Nutrition, v.19, p.211 217.

[32] Neu, D.H., Furuya, W.M., Yamashiro, D., Bittencourt, F. Moro, E. B., Fernandes, D. R. A. F., Boscolo, W. R., \& Feiden, A. Glycerol in the diet of Nile tilapia fingerlings. (2012).Agrarian Journal,v.5, p.288-294.

[33] Poleksic, V., \&Mitrovic-Tutundžic, V. Fish gills as a monitor of sublethal and chronic effects of pollution. In Müller, R.., \& Lloyd, R.Sublethal and chronic effects of pollutants on freshwater fish. (1994). Oxford: FishingNews Books, cap. 30, p. 339-352.

[34] Ranzani-Paiva M.J.T., Pádua S.B., Tavares-Dias, M., \& EGAMI M.I. Methods for haematological analysis in fish.(2013). 1.ed. Maringá: Eduem, 135p.

[35] Ranzani-Paiva M.J.T., \& Tavares-Dias, M. Erythrogram, visceral and somatic relation, hepatosomatic and somatic splenic in Mugil platanus Günther (Osteichthyes, Mugilidae) that were parasitized. (2002).Brazilian Journal of Zoology,v.19, n.3, p. $807-818$.

[36] Ranzani-Paiva, M.J.T., Ishikawa, C.M., Eiras, A.C., \& Felizardo, N.N. Hematological analysis in "cachara", Pseudoplatystoma fasciatum Linneus, 1766, in captivity. (2000a)European Aquaculture Society and Word Aquaculture Society, Nice, França,v. 28. 
[37] Ranzani-Paiva, M.J.T., Silva-Souza, A.T.; Pavanelli, C.G., Takemoto, R.M.,\& EIRAS, A.C. Hematological evaluation in commercial fish species from the floodplain of the upper Paraná River, Brazil. (2000b.).Acta Scientarium, v.22, n.2, p. 507-513.

[38] Raškovié, B.S., Stankovié, M.B., Markovié, Z.Z., \&Poleksié, V.D. Histological methods in the assessment of different feed effects on liver and intestine of fish. (2011). Journal of Agricultural Sciences, v. 56, p. 87-100.

[39] Ribeiro, R.D.X. Crude glycerin in the diet of confined lambs. (2015). 82 f. Tese (doutorado) Universidade Federal da Bahia, Escola de Medicina Veterinária e Zootecnia, Salvador.

[40] Rodrigues, A. P. O., Lima, A. F., Alves, A. L., Rosa, D. K., Torati, L. S.,\&Santos, V. R. V. Freshwater fish farming: multiplying knowledge.(2013). Editores Técnicos: Brasília - DF: Embrapa, 440 p.

[41] Romano, G.G., Menten, J.F.M., Freitas, L.W., Lima, M.B., Pereira, R.; Zavarize KC., \& DIAS, C.T.S. Effects of glycerol on metabolism of broilers fed diets containing increasing levels of glycerin. (2014). Brazilian Journal of Poultry Science, Campinas, v. 16, n. 1, p. 97-105.

[42] Schwaiger, J., Wanke, R., Adam, S., Pawert, M., Honnen, W., \& Triebskorn, R. The use of histopathological indicators to evaluate contaminant related stress in fish. Dordretch. (1997). Journal aquatic ecosystemstress recovery, v. 6, n. 1, p. 75-86.

[43] Shiau, S.Y. Utilization of carbohydrates in warmwater fish-with particularreference to tilapia, Oreochromis niloticusX O. aureus. (1997). Aquaculture, [s.1.], v.151, p. 79-96.

[44] Silva, A. S. E., Lima, J.T.A.X., \& Bianco, B.S. Hematology in fish. (2012)Journal Centaur,v.3, n.1, p.24-32.

[45] Tavares-Dias, M., Ishikawa, M.M., Martins, M.L., Satake, F., Hisano, H., PáduA, S.B.,Jerônimo, G.T., \& SÁ, A.R.S. de. Hematology: a tool for monitoring the health status of fish in culture. In: Saran Neto, A., Mariano, W. S.,\& Sória, S.F.P. (Ed.). Special topics in animal health and breeding. (2009). São Carlos: Pedro \& João Editores, p.43-80.

[46] Tavares-Dias, M., \& Moraes, F.R. Hematology of teleosteal fishes.(2004). Embrapa Amapá.Ribeirão Preto: M. Tavares-Dias, 144 p.

[47] Weiss, D.J., Wardrop, J., \& SCHALM, O.W. Schalm's Veterinary Hematology.(2010). 6.ed. Iowa: Black well Publishing, 1206p.

[48] Wintrobe, M.M. The volume and hemoglobin content of the red blood corpuscle: simple method of calculation, normal findings, and value of such calculations in the anemias. (1929).The American Journal of the Medical Sciences, v.177, p. 513-23. 